\title{
An Initial Study on Proficiency Scales for Business English for Chinese Users ${ }^{*}$
}

\author{
Cong Wang \\ Yihua School Xi'an Fanyi University, Xi'an, China \\ 424444902@qq.com
}

\begin{abstract}
In spite of the over 100 years of English education as a second language in China and the introduction of modern business English into the said country, standards for the proficiency of the language have never been set up. A possible solution, being explored by researchers at home and abroad, may be a set of proficiency scales to be developed from Chinese English users' perspective [1]. This essay, as a periodical achievement under a government-sponsored project, a Research into the Standards for Business English Proficiency in the Background of Fostering Xi'an into a Northwestern International City in China, tries to demonstrate the author's initial study on the issue and trigger more endeavors toward it.
\end{abstract}

Index Terms - business English, proficiency, standards, scales

\section{Introduction}

According to Sharma, a China-born Singapore scholar, English language has been introduced and taught in China for more than 170 years since 1840 s. So is the history of business English being applied by Chinese businessmen in their work [1]. However, whether a businessman speaks business English correctly and efficiently so that his foreign counterparts can easily understand still remains a question. The main reason may attribute to the different genres of business English education in Chinese colleges and universities. It was until 2003 that Business English was established as a major in a vocational college in Chinese Mainland. In 2007, UIBE was the first 4-year university which was approved by the Ministry of Education of China to set up its Business English major, one year ahead of its rival schools. But different institutes teach their students the same thing in quite varied ways. When the undergraduates in UIBE acquire knowledge and are trained relevant skills, the focus is put on language itself [2]. However, in Shandong Finance and Economics University, things are quite different. In fact, the major is taken there closer to another first-class discipline, Economics. Students there take less English lessons but more courses related to economics such as senior mathematics, microeconomics, macroeconomics, econometrics, international economics, etc [3]. Further to these experiments, other mainland universities are exploring their own genres, one of which, Xi'an Fanyi University mixes the former two into some kind of combination [4]. Nonetheless, all of the above only focus on the ways of how to execute business English education while little or no attention was paid to the result of it. Let alone the assessment of the result. The worse thing is that teachers and researchers hardly have access to the achievements of their foreign fraternity because the restrained internet sources. Some of them try to detect information by studying BEC papers from the test questions to their answers.

Attributive to the above situation, students of the same major arrive at quite varied ends: some get a degree in linguistics while others are granted a diploma for their study in economics. Undoubtedly, their skills and acquirement differ from each other considerably.

\section{The Main Questions of the Research}

A. How to assess the business English proficiency of graduates of the same major but from different colleges?

Apparently, a set of standards for business English listening, speaking, reading, writing and translation proficiency based on careful and predictive study may be a reasonable solution for the present bewildering.

First, they may work as reference for business English learners to assess their goals of and result from their learning.

Second, they may serve as reference for teachers to develop business English syllabus, curriculum provision and textbooks.

Thirdly, teachers can use them to define if they have achieved the teaching goals and to what extent they are supposed to teach the students.

Fourthly, their testing feature highlights their usage as a reference scale for public business test in establishing its proposition and scoring standards and therefore, they can corporate the syllabus of business English test of proficiency.

Fifthly, institutes and enterprises in China can apply them to recruit, train, test or evaluate their employees.

B. But how to set up a set of standards to evaluate if an English user reaches the respective standards or not?

To this end, a study on scales of business English proficiency in listening, speaking, reading, writing and translation for Chinese users comes on its way then.

A Research into the Standards for Business English Proficiency in the Background of Fostering Xi'an into a north western International City in China aims at exploring the construction of China Business English Proficiency Scale on an advanced, scientific, empirical and dynamic basis. The researchers under the project are trying to construct a scale

\footnotetext{
* This work is partially supported by Shaanxi Provincial Department of Education's 2012 Science and Technology Study Scheme Project Grant \# 13JK0322 to C. Wang.
} 
system both up to the international standard and concerning Chinese users' demand. In this research, the main issues are: the definition of business English proficiency and its content, theories about business English proficiency scale, developing process of business English proficiency scale.

Luckily, some achievements have arrived both in China and abroad by colleagues.

\section{Others' Study and Comments}

As reference [5] mentioned, western countries such as EC, Britain, the United States, Canada and Australia are more advanced in the field of research into language proficiency scale. As to business English proficiency scale study, the said nations that started earlier with scientific approaches have had some theoretical and mature achievements, which have won recognition in the world. Some of them are as follows :

\section{A. ALTE scale}

It is a scale made by Association of Language Testers in Europe in 2002 in which language proficiency is evaluated by 6 grades from low to high: Breakthrough level, 1(Way stage User), 2(Threshold User), 3(Independent User), 4(Competent User) and 5(good User). Mainly ALTE scale is used as assessing standard for English levels in the sphere such as society, tourism, working places and schools. Each grade is described in four aspects: listening, speaking, reading and writing along with samples [6].

\section{B. CEF scale}

This scale is stipulated by the European Council in 2001 and cover 14European languages. CEF is believed the present most authoritative scale in the world.

\section{BULATS / BEC}

BULATS is a test developed for Speakers of Other Languages I and outside Britain by Cambridge University, which was introduced into China in 2003. It is designed to test the English proficiency of those whose work is closely related to enterprises. The result of BULATS varied from the lowest score 0 to the highest 5 .

With the Chinese name BEC, the test is classified in three degrees: Preliminary, Vantage and Higher Level, and gives reliable evaluation to candidates in listening, speaking, reading and writing. But there are arguments that first it does not evaluate translation proficiency, which is weighed a lot by Chinese users and second, its glossary appears general instead of specific to Chinese users, especially the technical terms. What's more, some Chinese users criticize BEC that its distinction degree is not as good as supposed.

\section{CLB2000(Canadian Language Benchmarks, 2000)}

As shown in Table 1, this scale gives 3 stages and totally 12 degrees in describing the standards for listening, speaking, reading and writing respectively in communication that English learners should achieve.

In mainland of China, at present there is no generally accepted foreign language proficiency scale or system. But some tests for business English levels, such as CNBECT, have been developed and implemented since 2006.

TABLE 1 CLB2000 writing proficiency scale

\begin{tabular}{|c|c|c|c|}
\hline stage & degree & description & writing proficiency \\
\hline \multirow{4}{*}{ preliminary } & 1 & initial & \multirow{4}{*}{$\begin{array}{l}\text { Can write simple text in social } \\
\text { communication, information } \\
\text { retelling, business/service and } \\
\text { information expression. }\end{array}$} \\
\hline & 2 & developing & \\
\hline & 3 & qualified & \\
\hline & 4 & fluent & \\
\hline \multirow{4}{*}{ middle } & 1 & initial & \multirow{4}{*}{$\begin{array}{l}\text { Can write more difficult text } \\
\text { in social communication, } \\
\text { information recording, } \\
\text { business/service as well as } \\
\text { information and idea } \\
\text { expression. }\end{array}$} \\
\hline & 2 & developing & \\
\hline & 3 & qualified & \\
\hline & 4 & fluent & \\
\hline \multirow{4}{*}{ advanced } & 1 & initial & \multirow{4}{*}{$\begin{array}{l}\text { Can write complex text in } \\
\text { social communication, } \\
\text { information retelling, } \\
\text { business/service and } \\
\text { expression. }\end{array}$} \\
\hline & 2 & developing & \\
\hline & 3 & qualified & \\
\hline & 4 & fluent & \\
\hline
\end{tabular}

\section{E. CNBECT}

In 2006, China Academy of International Trade developed CNBECT and has been carrying out the nationalwide test since then. The test has two classes, Class I and Class II, but has been facing with continuous challenges against its reliability, validity and discrimination degree due to the absence of a reliable business English proficiency scale as its basis.

\section{The Approaches Possibly to Be Used in the Author's Present Research}

This research is an applied one and the researchers plan to conduct it by quantitative analysis and qualitative analysis on results of their questionnaire survey and interviews in some selected foreign trade enterprises in Shaanxi province of China. The data will be processed with Microsoft Excel 2003 for frequency.

\section{The Possible Obstacles}

At present, there is scarce study on domestic standards of business English proficiency so that relevant data, information or research achievements are rare.

Although western countries are mature in the similar research field, but the reliability, validity and discrimination degree of the above-mentioned tests are doubtable because their standards and scales are based on English as candidates' mother language or first language. Therefore, it is hardly possible for Chinese researchers to take their western colleagues' results as basis of their own study.

\section{Reply to the Questions}

In reply to the questions set forth at the beginning of the thesis, the researchers are planning to develop their own. Chinese Business English Proficiency Scale (CBEPC) in five aspects ranging from listening, speaking, reading, writing to 
translation. Namely, the scale will be composed of 5 subscales as follows:

- Business English listening proficiency scale (BELPS)

- Business English Speaking proficiency scale (BESPS)

- Business English reading proficiency scale (BERPS)

- Business English Writing proficiency scale (BEWPS)

- Business English Translation proficiency scale (BETPS)

\section{Conclusions}

What this research is supposed to achieve?

First, it will define business English proficiency which is to serve Chinese users. Second, it aims at putting forward a constitutional model for China-featured business English proficiency theory. Thirdly, it will argue for the basis of the expected theory. Fourthly, it will explore the way for preliminary development of China-featured business English proficiency scale. Finally, it will end at an initial Chinese Business English Proficiency Scale [7].

The researchers hope all the above will give a push to business learning and teaching in mainland of China.

\section{The Limitation of the Present Study}

As little access to foreign colleagues' achievements can be got by the researchers, and the questionnaire survey and interviews will be conducted within Shaanxi Province, the reliability, validity and discrimination degree will surely be affected to some extent.

\section{Vision: Where do we go from Here?}

This research aims at providing theoretical ground for construction of standard for business English proficiency in the environment of fostering Xi'an into a north western International City in China. A Chinese Business English Proficiency Scale is its terminal. Verification of the scale's reliability, validity and discrimination degree as well as later improvement of it will be done in future research.

\section{Acknowledgement}

The author thanks all her co-workers for their work and effort under the Shaanxi Provincial Department of Education's 2012 Science and Technology Study Scheme Project.

\section{References}

[1] Sharma, "a Study on the History of English Education as a Second Language in China", unpublished, 2013

[2] English School of UIBE, Business English Syllabus, unpublished, 2007

[3] SFEU, Business English Syllabus, unpublished, 2010

[4] XFU, Business English Syllabus, unpublished, 2013

[5] B. Han, "a comment on western Language Proficiency Scales" $J$, Foreign Language Teaching and Research, vol. 38 no. 6, 2006

[6] D. Wang, "a Research into Test Questions of Chinese Entry Examination for College Based on Real Evaluation", China Test (research version) $J$, No. 8, 2008

[7] H. Yang, Z. Zhu and X. Fang, the Development of National Common Framework of Language Proficiency Scales----Principles, Approaches, and Validation Study, Shanghai Foreign Language Education Press, October 2012 